\title{
BRFK 140 1
}

\section{Könyvismertetés}

\section{NÉMETH Zsolt ${ }^{\circledR}$}

Az Előszóból (Papp Károly belbiztonsági államtitkár) megtudjuk, hogy ez a könyv visszaemlékezés, „tisztelgés az összes budapesti rendőr előtt, akik 140 év alatt munkájukkal hozzájárultak, hogy Magyarország fővárosa ma már az egyik legbiztonságosabb európai főváros". Az Ajánlás (Balogh János altábornagy, országos rendőfőkkapitány) leszögezi, hogy itt, a fővárosban „nem pusztán több ügyet kell kezelni, hanem gyakran rendkívüli jelentőségúeket, és ez megköveteli, hogy a budapesti rendőrök különleges felkészültséggel és rutinnal rendelkezzenek".

Az Elöszó és az Ajánlás után rövid vázlat következik (15 oldal) a BRFK történetéről, amely 1881-ben kezdődött a Budapesti Magyar Királyi Államrendőrség létrejöttével. Az elnevezésből látható, hogy „államosítás” történt, ezt megelőzően a rendőrség az önkormányzatokhoz tartozott. A vonatkozó törvénycikk hármas rendőri feladatkört határozott meg, úgymint figyelés, megelőzés és felfedezés. Ez mintha a máig aktuális sorrendet jelezné: tartsa szemmel a rendőrség a közösség életének rendjét, a bontakozó bajt előzze meg, és ha mégis megtörtént, fedezze fel, vagyis vizsgálja ki. Már az első években megszervezték a sajtószolgálatot, naponta a déli órákban tájékoztatták a közvéleményt a bűnesetekről, a nyomozások helyzetéről. A múlt emlékeit is megőrzendőnek tartva 1908-ban létrehozták a Bünügyi Múzeumot, és megalkották a rendbiztos megnevezést a rendőr szó helyett, innen ered a „biztos úr” ma is előforduló megszólítása, 1933-ban a kard és a lőfegyver mellé rendszeresítették a gumibotot. Nyomon követheti az olvasó a szervezet és múködése fejlődését, külön részletezve a II. világháború után történteket a rendszerváltásig, méghozzá két ütemben, a töréspont a forradalom éve, 1956. A rendszerváltás rendőrsége a nagy újrakezdést élte meg: ismét lett törvény a rendőrségről, kicserélődött az állomány, majd felépült a Teve utcai komplex rendőrpalota. A történeti részből hiányoljuk Trianon hatását a rendészeti müködésre, ezt kísérelte meg pótolni a Magyar Rendészet 2021-es 1. számában.

400 oldalas a mú, a terjedelem döntő hányada (250 oldal) a tárgyalt 140 év fókapitányait mutatja be, összesen 35 rendőrfőnököt. Érdekes elképzelés, hogy a regnálásuk idejére eső egy-egy „korszakos”-nak tartott búnügyet részletez a könyv.

BRFK 140. Budapest, Budapesti Rendőr-főkapitányság, 2021.

Németh Zsolt PhD. ny. r. ezredes, egyetemi docens, Nemzeti Közszolgálati Egyetem Rendészettudományi Kar Kriminológiai Tanszék.

Zsolt Németh PhD, ret. Police Colonel, University of Public Service, Faculty of Law Enforcement, Department of Criminology, Associate Professor. E-mail: kriminologus@gmail.com 
A legtöbb, 29 eset, brutális gyilkosságot mutat be. A kivételek közé tartozik Domján Edit öngyilkossága (1972), a West-Balkán tragédiája (2011) és a Hableány katasztrófája (2019). Másfajta kivételek sorába Sédey Gyula (1945), Sólyom László (1946) és Kopácsi Sándor (1956) tartozik, ahol a fókapitány tragikus, személyes sorsát ismerjük meg: politikai ellenfélként bántak el velük. A gyilkosságok között több darabolós eset, valamint rendőrhalált is okozó van. Mindegyik bűnügy érdekfeszítő, izgalmas leírás, más kérdés, hogy vajon ezek a bűnügyek jellemzők voltak-e az adott kor társadalmi, gazdasági helyzetére. A szerzők a korabeli sajtóhírekre támaszkodtak, így érthető, hogy a nyomozás olyan részletei, amelyek a kor tudományos és technikai színvonalát érzékeltetnék, és főleg a rendőrök személye, többnyire rejtve marad, noha kíváncsiak lennénk rá. A legfőbb tanulság talán az, hogy kíméletlen, leszámolásos, illetve rablási szándékú gyilkosságok minden időben voltak és vannak.

Érdekes megfigyelni, hogy míg 1945 előtt a főkkapitányok a kinevezésük előtt ügyészi és közigazgatási pályán voltak, majd 1956-ig a politikai megbízhatóság volt a legfőbb érték, azt követően és napjainkban szakmai karrierek bontakoznak ki. Egy főkapitányi portré azonban hiányzik: Kovács Nagy Pálnál pedig szerepel, hogy elődje, Petrányi György öt hónapig vezette a főkapitányságot, szóba került személye a bevezető történeti részében is, hogy egészségügyi okból saját maga kérte a felmentését (1944), Petrányi életútja mégis kimaradt a kötetből.

Minduntalan felbukkanó adalék az állandó létszámhiány a rendőri munka frontján, a vezetőváltással együtt járó folytonos átszervezés, és a vezetői helyek csökkentésének szándéka. Ezek minden bizonnyal a fizikai törvények erejével elöálló jelenségek, a megoldásukkal mintha nem is kísérleteznének, ennek a kötetnek sem lehetett ez a célja, még az okok feltárása sem. Érthető és talán jogos a visszatérő rosszalló megjegyzés az 1956-os forradalom elötti vezetôk pártállam iránti készségessége miatt, noha egy rendőri vezetőnek a mindenkori kormány iránti lojalitása minden bizonnyal elengedhetetlen, Kopácsi Sándoron kívül - a különleges történelmi helyzetben - nem is volt erre példa, és ma sem lehet másként.

A könyv harmadik részében Múltunk és jelenünk másképp következik. Itt szóba kerülnek a Teve utcai rendőrpalota építésének részletei, az épület jellemzői. A Detektív testület címú részben régmúltból származó, valamint napjaink szolgálati dokumentumai kapnak helyet, többek között az 1990-es taxisblokád néhány rendőrségi irata. És végül sok-sok érdekes fénykép a 19. század végétől napjainkig, a 21. század elejéig a főváros és rendőrsége mindennapjairól.

A kötet szerkesztője és egyik szerzője Nothoff Ingrid rendőr őrnagy, a szerzők: Dobó Katalin Anita r. százados, Szabó Bettina r. főhadnagy és Sári Tamás Dávid r. főhadnagy, az anyanyelvi lektor: Vitéz Ferenc. Látható, hogy az alkotók nem történészek, de törekedtek a múlt hiteles feldolgozására. A forrásjegyzék 19 oldalon közel 400 tételt tartalmaz, néhány szakirodalmat, de inkább sajtótermékeket (nyomtatott és online formát vegyesen) sorol. Nem alkalmaznak hivatkozást, így az olvasó további tájékozódása meglehetősen nehézkessé válik. 
A BRFK 140 ünnepi emlékező kötet, az ünnepelt szervezet saját vállalkozása, hatalmas munka, izgalmas és érdekes körkép. Néhány dolgot kifogásoltunk ugyan, és még lehetne mást is, például a képzés, képzettség ismérveit, de nem lehetünk telhetetlenek, így is tekintélyes tartalmú és méretủ mủ született. Egy szöveggondozói fázis is jót tett volna még a végeredménynek, jó néhány apró hiba, elütés, sôt a fogalmazás esetenkénti megbicsaklása kiszűrhető lett volna. De ezzel együtt is, elismerésünk az alkotók kitartó és szorgalmas munkája iránt, bizton állíthatjuk, hogy az Ajánlás mottójának teljesüléséhez - „Tiszteld a múltat, hogy érthesd a jelent, és munkálkodhass a jövőn!” - jelentősen hozzájárultak. 